\title{
Syntheses and X-Ray Crystal Structures of Organoantimony Diazides
}

\author{
Benjamin Lyhs, Dieter Bläser, Christoph Wölper, and Stephan Schulz*[a]
}

\begin{abstract}
Antimony(III) complexes of the general type $\mathrm{LSbF}_{2}\left(\mathrm{~L}^{1}=\left[t \mathrm{BuC}(\mathrm{NiPr})_{2}\right] \mathbf{3}^{3} \mathrm{~L}^{2}=\left[t \mathrm{BuC}(\mathrm{NDipp})_{2}\right](\mathrm{Dipp}=\right.$ 2,6-i $\left.\mathrm{Pr}_{2}-\mathrm{C}_{6} \mathrm{H}_{3}\right)$ 4) and $\mathrm{LSb}\left(\mathrm{N}_{3}\right)_{2}\left(\mathrm{~L}^{1}\right.$ 6, $\mathrm{L}^{2}$ 7) were prepared in high yields and characterized by elemental analyses, NMR and IR spectroscopy and single crystal X-ray diffraction. Moreover, the solid state structures of $\left[\mathrm{L}^{2} \mathrm{SbF}_{2}\right]\left[\mathrm{L}^{2} \mathrm{Li}\right] \mathbf{5},\left[\mathrm{L}^{2} \mathrm{AlH}\right]_{2} 1$ and $\left[\mathrm{L}^{\prime} \mathrm{H}\right]\left[\mathrm{L}^{\prime} \mathrm{K}(\mathrm{thf})_{3}\right] 2\left(\mathrm{~L}^{\prime}=\mathrm{HC}(\mathrm{NDipp})_{2}\right)$ are described, in which the $\mathrm{Li}(\mathbf{5})$ and $\mathrm{K}$ atoms (2) adopt rather unusual coordination modes.
\end{abstract}

Keywords: Antimony $\bullet$ Azide $\bullet \mathrm{N}$ ligands $\bullet \mathrm{X}$-ray diffraction

\section{Introduction}

The capability of $\mathrm{N}, \mathrm{N}^{\prime}$-chelating ligands such as amidinates $\mathrm{I}^{[3]}$ guanidinates $\mathrm{II}^{[2]}$ and $\beta$-diketiminates III $^{[1]}$ to coordinate a large variety of main group and transition metals in a monodentate $\left(\eta^{1}, \mathbf{i}\right)$, chelating $\left(\eta^{2}\right.$, ii) or bridging monodentate $\left(\mu-\eta^{l}-\eta^{l}\right.$, iii) fashion and the easy tunability of their steric and electronic properties by variation of the substituents $R$ and $R^{\prime}$ render them very suitable in organometallic chemistry. ${ }^{[4]}$ As a consequence, these complexes have been largely investigated in catalysis ${ }^{[5]}$ and material sciences. ${ }^{[6]}$ Moreover, $\mathrm{N}, \mathrm{N}^{\prime}$-chelating ligands were found to be extremely suitable for the synthesis of main group metal complexes in rather unusual oxidation states such as low-valent group $2,,^{[7]}$ group $13,{ }^{[8]}$ group $14^{[9]}$ and group 15 element complexes. $^{[10]}$

Due to our long-time interest in organobismuth and organoantimony chemistry, ${ }^{[11]}$ we started only recently to synthesize complexes of the general type $\mathrm{LECl}_{2}(\mathrm{E}=\mathrm{Sb}, \mathrm{Bi})$ containing $\mathrm{N}, \mathrm{N}^{\prime}$-chelating ligands of types I - III and reported on the solid state structures of several amidinate dichlorostibines and -bismuthines $\mathrm{LECl}_{2}$. These complexes were obtained in high yields by simple metathesis reaction. ${ }^{[12]}$ Surprisingly, only a very few complexes of the type LEX 2 containing the heaviest group 15 elements, $\mathrm{Sb}$ and $\mathrm{Bi}$, have been structurally characterized prior to our studies, ${ }^{[10,13]}$ most likely due to their tendency to form elemental antimony and bismuth under typical metathesis reaction conditions. Thus-prepared complexes were expected to be suitable candidates for the synthesis of the corresponding hydride, fluoride and azide complexes $\operatorname{LSbR} R_{2}\left(R=H, F, N_{3}\right)$ by metathesis reactions as well as distibenes $\mathrm{LSb}=\mathrm{SbL}$ via reductive coupling reactions as was reported for 
guanidinato-bridged diarsene complexes, which were formed by reaction of the corresponding dichloroarsine complex with $\mathrm{KC}_{8} \cdot{ }^{[10 \mathrm{a}]}$

\section{Scheme 1 here}

Scheme 1. N, N' chelating ligands and general coordination modes.

Unfortunately, reactions of $\mathrm{LSbCl}_{2}$ with several fluoride and hydride transfer reagents as well as with a variety of reducing reagents completely failed to give the corresponding fluorides, hydrides and distibenes. However, the structures of two complexes $\left[\mathrm{L}^{2} \mathrm{AlH} \mathrm{H}_{2}\right]_{2} \mathbf{1}\left(\mathrm{L}^{2}=t \mathrm{BuC}(\mathrm{NDipp})_{2}\right)$ and $\left[\mathrm{L}^{\prime} \mathrm{H}\right]\left[\mathrm{L}^{\prime} \mathrm{K}(\mathrm{thf})_{3}\right] \mathbf{2}\left(\mathrm{L}^{\prime}=\mathrm{HC}(\mathrm{NDipp})_{2}\right)$, which were obtained as by-products from reactions with elemental potassium and $\mathrm{LiAlH}_{4}$, respectively, are briefly described. As a consequence, we investigated metathesis reactions of $\mathrm{SbF}_{3}$ with Li-amidinate complexes. Two amidinate-difluorostibines $\mathrm{LSbF}_{2}\left(\mathrm{~L}^{1}=t \mathrm{BuC}(\mathrm{NiPr})_{2}\right.$ 3; $^{2} \mathrm{~L}^{2}=t \mathrm{BuC}(\mathrm{NDipp})_{2}$ 4; $\left.\mathrm{Dipp}=2,6-i \mathrm{Pr}_{2}-\mathrm{C}_{6} \mathrm{H}_{3}\right)$ were obtained and structurally characterized. These fluorides are suitable starting reagents for the synthesis of the corresponding diazides $\mathrm{LSb}\left(\mathrm{N}_{3}\right)_{2}\left(\mathrm{~L}^{1}=t \mathrm{BuC}(\mathrm{NiPr})_{2} 6 ; \mathrm{L}^{2}=t \mathrm{BuC}(\mathrm{NDipp})_{2} 7\right)$, which to the best of our knowledge represent the first structurally characterized organometallic complexes of the type $\operatorname{RSb}\left(\mathrm{N}_{3}\right)_{2}$.

\section{Results and Discussion}

Reactions of $\mathrm{LSbCl}_{2}$ with fluoride transfer reagents such as $\mathrm{NaF}$, and $\mathrm{AgF}$ and $\mathrm{Me}_{3} \mathrm{SnF}$ in different solvents failed to give the corresponding difluorostibines. Comparable findings have been previously reported for orgonobismuth complexes. ${ }^{[14]}$ In addition, reduction reactions of $\mathrm{LSbCl}_{2}$ with several reducing agents ( $\mathrm{Na}, \mathrm{K}$, $\mathrm{KC}_{8}$, Na-naphthalide, Mg) as well as reactions with hydride transfer reagents $\left(\mathrm{NaH}, \mathrm{KH}, \mathrm{LiBHEt}_{3}, \mathrm{LiAlH}_{4}\right)$ in different solvents $\left(\mathrm{Et}_{2} \mathrm{O}, \mathrm{THF}, \mathrm{CHCl}_{3}\right)$ only yielded black, insoluble precipitates. However, a very few colorless crystals of $\left[\mathrm{L}^{2} \mathrm{AlH} \mathrm{H}_{2}\right]_{2} \mathbf{1}$ and $\left[\mathrm{L}^{\prime} \mathrm{H}\right]\left[\mathrm{L}^{\prime} \mathrm{K}(\mathrm{thf})_{3}\right] \mathbf{2}$ were obtained from the reactions of the corresponding dichlorostibines with $\mathrm{K}$ and $\mathrm{LiAlH}_{4}$, respectively, upon storage of the filtrates at $-30{ }^{\circ} \mathrm{C}\left(\mathrm{THF} \mathrm{1;} \mathrm{Et}_{2} \mathrm{O}\right.$ 2). Surprisingly, the $t$-Bu group of the amidinate backbone in $\mathbf{2}$ was replaced by a $\mathrm{H}$-atom, hence resulting in the formation of a potassium formamidinate complex, which co-crystallizes together with the corresponding formamidine. Single crystals of $\mathbf{1}$ and $\mathbf{2}$ were obtained from solutions in $\mathrm{Et}_{2} \mathrm{O}(\mathbf{1})$ and $\operatorname{THF}(\mathbf{2})$ in very low yields (<2\%). 1 adopts a dimeric structure in the solid state with bridging hydrides and the fivefold coordinated Al atoms are coordinated by $\mathrm{N}, \mathrm{N}^{\prime}$-chelating amidinate groups. In contrast, the monoanionic formamidinate in $\mathbf{2}$ 
coordinates to the $\mathrm{K}^{+}$ion in a $\eta^{1}-\mathrm{N}, \eta^{6}$-arene mode. Since the structures of both $\mathbf{1}^{[15]}$ and $\mathbf{2}^{[16]}$ have been previously reported, they are not discussed here in detail. ${ }^{[17]}$

Organoantimony(III)fluorides surprisingly are rather rare ${ }^{[18]}$ and most of them constitute monofluorides $\mathrm{R}_{2} \mathrm{SbF}$ such as $\left[\mathrm{Ph}_{2} \mathrm{SbF}_{2}{ }^{[19]}\right.$ and others. ${ }^{[20]}$ Only three $\mathrm{Sb}(\mathrm{III})$ difluorides containing $\mathrm{Y}, \mathrm{C}, \mathrm{Y}$-chelating pincer ligands $(\mathrm{Y}=$ $\mathrm{OR}, \mathrm{NR}_{2}$ ), which were prepared by reactions of the corresponding dichlorides with $\mathrm{Me}_{3} \mathrm{SiF}$, have been structurally characterized. ${ }^{[21]}$ In contrast, $\mathrm{LSbF}_{2}$ complexes containing $\mathrm{N}$ - or O-substituents have been investigated to a larger extent and several complexes have been structurally characterized. ${ }^{[22]}$ Since halide exchange reactions between chlorostibines $\mathrm{LSbCl}_{2}$ and fluoride transfer reagents in our hands failed to give the corresponding stibinofluorides $\mathrm{LSbF}_{2}$, we reacted $\mathrm{SbF}_{3}$ with an equimolar amount of the corresponding $\mathrm{Li}$ amidinate in $\mathrm{Et}_{2} \mathrm{O} . \mathrm{L}^{1} \mathrm{SbF}_{2} 3$ and $\mathrm{L}^{2} \mathrm{SbF}_{2} 4$ were formed in almost quantitative yields. Moreover, [ $\left.\mathrm{L}^{2} \mathrm{SbF}-\mu-\mathrm{F}-\mathrm{LiL}^{2}\right] \mathbf{5}$ was obtained as by-product in very low yield from the reaction of $\mathrm{SbF}_{3}$ with a slight excess of in situ prepared $\mathrm{LiL}^{2}$.

\section{Scheme 2 here}

Scheme 2. Synthesis of complexes 3 and $\mathbf{4}$.

${ }^{1} \mathrm{H}$ and ${ }^{13} \mathrm{C}$ NMR spectra of $\mathbf{3}$ and $\mathbf{4}$ show the expected resonances due to the organic substituents of the amidinate moiety, which occur in the same range as was observed for the corresponding dichlorostibines. The ${ }^{19}$ F NMR spectra show resonances at -107.9 (3) and $-115.3 \mathrm{ppm}$ (4), which is slightly downfield shifted compared to difluorostibines ${ }^{[21]}$ and to organoantimony(V)fluorides, ${ }^{[23]}$ which typically showed resonances around $-150 \mathrm{ppm}$. The IR spectra of $\mathbf{3}$ and $\mathbf{4}$ show strong absorption bands due to the axial $\left(482.0 \mathbf{3}, 516.2 \mathrm{~cm}^{-1}\right.$ 4) and equatorial $\mathrm{Sb}-\mathrm{F}$ groups $\left(559.03,587.7 \mathrm{~cm}^{-1} 4\right)$ as was observed for $\left[\left(\mathrm{Et}_{3} \mathrm{P}=\mathrm{N}\right) \mathrm{SbF}_{2}\right]_{2} \cdot{ }^{[22 a]}$

Single crystals of $\mathbf{3}$ and $\mathbf{4}$ were obtained from solutions in $\mathrm{CHCl}_{3}$ after storage at $-30{ }^{\circ} \mathrm{C}$ for $48 \mathrm{~h}$, whereas those of 5 were directly obtained from the $\mathrm{Et}_{2} \mathrm{O}$ solution at ambient temperature.

\section{Figure 1 here}

Figure 1. Molecular structure and atom numbering scheme of $\mathrm{L}^{1} \mathrm{SbF}_{2} 3$; thermal ellipsoids are drawn at the $50 \%$ probability level. Hydrogen atoms and and the $\mathrm{CHCl}_{3}$ molecule have been omitted for clarity. Sb1-N1 2.2189(12), Sb1-N2 2.0883(12), Sb1-F1 1.9216(10), Sb1-F2 1.9863(10), N1-C1 1.3157(18), N2-C1 1.3603(17); 
N1-C1-N2 107.52(12), N1-Sb1-N2 60.06(4), C1-N1-Sb1 93.54(9), C1-N2-Sb1 98.13(9), F1-Sb1-F2 83.76(5), F1Sb1-N1 84.73(4), F1-Sb1-N2 105.29(5), F2-Sb1-N1 141.08(5), F2-Sb1-N2 87.59(4).

\section{Figure 2 here}

Figure 2. Molecular structure and atom numbering scheme of $\mathrm{L}^{2} \mathrm{SbF}_{2} 4$; thermal ellipsoids are drawn at the $50 \%$ probability level. Hydrogen atoms and the $\mathrm{CHCl}_{3}$ molecule have been omitted for clarity. Sb1-N1 2.300(2), Sb1N2 2.100(3), Sb1-F1 1.897(2), Sb1-F2 1.9603(18), N1-C1 1.311(4), N2-C1 1.359(4); N1-C1-N2 108.5(2), N1-Sb1N2 58.78(9), C1-N1-Sb1 92.29(17), C1-N2-Sb1 100.01(18), F1-Sb1-F2 87.84(9), F1-Sb1-N1 85.83(8), F1-Sb1-N2 98.59(10), F2-Sb1-N1 142.47(8), F2-Sb1-N2 85.81(9).

The complexes crystallize in the triclinic space group $P-1(3,4)$ and the monoclinic space group $C 2 / c(5)$, respectively. $\mathbf{3}$ and $\mathbf{4}$ each contain an additional $\mathrm{CHCl}_{3}$ molecule in the crystal lattice, whereas $\mathbf{5}$ was obtained as solvent-free complex. $\mathbf{3}$ and $\mathbf{4}$ are both monomeric in the solid state without any further (weak) contacts to fluorine atoms of adjacent complexes as was reported for the weakly bound dimer [2,6$\left.\left.\left(\mathrm{MeOCH}_{2}\right)_{2} \mathrm{C}_{6} \mathrm{H}_{3}\right] \mathrm{SbF}_{2}\right]_{2} \cdot{ }^{[21]}$ The amidinate moieties in $\mathbf{3}$ and $\mathbf{4}$ serve as $\mathrm{N}, \mathrm{N}^{\prime}$-chelating $\left(\eta^{2}\right)$ four-electron donor ligands as was observed for the corresponding dichlorides $\mathrm{LSbCl}_{2}{ }^{[12]}$ The coordination geometry of $\mathbf{3}$ and $\mathbf{4}$ can be described as heavily distorted "saw-horse" conformation, in which the stereochemically active electron lone pair adopts an equatorial position. Analogous structural findings were reported for $\mathrm{PhC}\left(\mathrm{NSiMe}_{3}\right)_{2} \mathrm{SbCl}_{2}{ }^{[13 a]}$ and guanidato dichloroarsines, ${ }^{[10 a]}$ respectively. The N-Sb-F axis significantly deviates from linearity (N1-Sb1-F2 $141.08(5)^{\circ} 3$; N1-Sb1-F2 $\left.142.47(8)^{\circ} 4\right)$ due to the larger steric demand of the electron lone pair. In addition, the bond lengths to the axial-bonded ligands (3: Sb1-F2 1.9863(10); Sb1-N1 2.2189(12); 4: Sb1-F2 1.9603(18); Sb1N1 2.300(2) Å) are significantly elongated compared to the equatorial-bonded ligands (3: Sb1-F1 1.9216(10); Sb1-N2 2.0883(12); 4: Sb1-F1 1.897(2); Sb1-N2 2.100(3) Å) and the Sb1-F1 bond length observed for 4 is significantly shorter compared to Sb-F bond lengths reported for organoantimony(III)difluorides, which typically range from 1.94 to $1.98 \AA .{ }^{[21]}$ The sum of bond angles at C1 $(360.03,4), N 1(360.03 ; 357.44)$ and N2 (358.2 $3 ; 359.04)$ indicate $\mathrm{sp}^{2}$-hybridized carbon and nitrogen atoms with the $\pi$-electrons rather localized as is indicated by the different C-N bond lengths (3: C1-N1 1.3157(18); C1-N2 1.3603(17); 4: C1-N1 1.311(4); C1-N2 1.359(4) Å). Similar structural parameters were reported for comparable group 15 element complexes. ${ }^{[10 a, 13 a]}$ 
Figure 3. Molecular structure and atom numbering scheme of $\left[\mathrm{L}^{2} \mathrm{SbF}_{2}\right]\left[\mathrm{L}^{2} \mathrm{Li}\right] \mathbf{5}$; thermal ellipsoids are drawn at the $50 \%$ probability level. Hydrogen atoms have been omitted for clarity ( $F 2$ is disordered and the minor component is shaded). Sb1-N1 2.093(3), Sb1-N2 2.258(3), Sb1-F1 2.027(2), Sb1-F2 1.860(3), Li1-F1 1.785(7), Li1N3 1.95888), Li1-C48 2.313(8), Li1-C53 2.477(8), Li1-C49 2.558(5), N1-C1 1.356(5), N2-C1 1.315(5); N1-C1-N2 107.8(4), N1-Sb1-N2 59.36(12), C1-N1-Sb1 99.5(3), C1-N2-Sb1 93.2(2), F1-Sb1-F2 88.73(12), F1-Sb1-N1 83.51(11), F1-Sb1-N2 142.69(11), F2-Sb1-N1 92.92(14), F2-Sb1-N2 89.62(13), Sb1-F1-Li1 2 142.2(3), N3-C31-N4 120.7(4), N3-Li1-C48 75.5(3).

In complex $\mathbf{5}$, one F-atom of the $\mathrm{LSbF}_{2}$ complex additionally coordinates to an adjacent Li-ion, which is additionally coordinated by an amidinate group in a $\eta^{1}-\mathrm{N}, \eta^{3}$-arene mode. This is a rather unusual coordination mode for the hard Li ion (according to the HSAB principle), since Li ions are typically coordinated by the atoms with the highest negative charge. As a consequence, the $\mathrm{N}, \mathrm{N}^{\prime}$-chelating mode is typically observed for Li formamidinates, amidinates, guanidinates and $\beta$-diketiminates, respectively. In contrast, soft main group metals such as $\mathrm{Na}^{+}, \mathrm{K}^{+}$or $\mathrm{Tl}^{+}$tend to increase their coordination number by $\pi$-coordination of the aromatic substituents as was observed in $\mathbf{2}^{[16]}\left[\mathrm{K}\left\{\left(\eta^{6}-\mathrm{Mes}\right) \mathrm{NC}(\mathrm{H}) \mathrm{N}(\mathrm{Mes})\right\}\left\{\left(\eta^{6}-\mathrm{Mes}\right) \mathrm{NC}(\mathrm{H}) \mathrm{NH}(\mathrm{Mes})\right]{ }^{[24]}\right.$ and others. ${ }^{[25]}$ To the best of our knowledge, $\left[\mathrm{Cy}_{2} \mathrm{NC}(\mathrm{NDipp})_{2}\right] \mathrm{Li}($ thf) containing a sterically demanding guanidinate ligand is the only structurally characterized Li-complex that exhibits an analogous $\eta^{3}$-coordination of the arene moiety. ${ }^{[26]}$ In contrast, the $\mathrm{K}^{+}$ion in $\mathbf{2}$ is $\eta^{6}$-coordinated by the arene moiety. The delocalization of the $\pi$-electrons in the Liamidinate backbone of $\mathbf{5}$ is only slightly distorted (N3-C31 1.342(5), N4-C31 1.319(5) Å) and the N3-C31-N4 bond angle $\left(120.7(4)^{\circ}\right)$ as observed for the Li-amidine backbone is in the upper range typically reported for Liamidinate complexes containing $\eta^{2}$-chelating amidinates. ${ }^{[27]}$ This finding clearly results from the reduced ring strain due to the $\eta^{3}$-arene coordination mode. The terminal Sb-F bond $(1.860(3) \AA)$ is significantly shorter compared to the bridging Sb-F bond $(2.027(2) \AA)$ as well as to the $\mathrm{Sb}-\mathrm{F}$ bond lengths in $\mathrm{SbF}_{3 .}{ }^{[28]}$

A convenient route for the synthesis of main group element azides is the reaction of the corresponding fluoride with $\mathrm{Me}_{3} \mathrm{SiN}_{3}$ since the thus-formed $\mathrm{Me}_{3} \mathrm{SiF}$, whose formation is thermodynamically strongly favored due to the strong Si-F bond, can easily removed in vacuo, yielding the desired azide complexes. Moreover, $\mathrm{Me}_{3} \mathrm{SiN}_{3}$ can also serve as solvent in these reactions. $\mathrm{Sb}$ (III)azides have been only scarcely synthesized ${ }^{[29]}$ and to the best of our knowledge, $\mathrm{Sb}\left(\mathrm{N}_{3}\right)_{3}{ }^{[30]}$ and mixed halide/azide complexes $\left.\left(\mathrm{SbCl}\left(\mathrm{N}_{3}\right)_{2}{ }^{[31]} \mathrm{SbCl}_{2} \mathrm{~N}_{3} \text { (pyridine }\right)_{2}{ }^{[32]}\right)$ as well as 
three monoazide complexes $\mathrm{L}_{2} \mathrm{SbN}_{3}{ }^{[33]}$ including $\mathrm{Me}_{2} \mathrm{SbN}_{3}{ }^{[34]}$ represent the only structurally characterized $\mathrm{Sb}(\mathrm{III})$ azides. The same is true for $\mathrm{Bi}(\mathrm{III})$ azides, even though Schulz et al. very recently reported on the synthesis of $\mathrm{Bi}\left(\mathrm{N}_{3}\right)_{3}{ }^{[35]}$ Moreover, the structures of $\mathrm{MeBi}\left(\mathrm{N}_{3}\right)_{2}{ }^{[34]}$ and $\mathrm{Me}_{2} \mathrm{BiN}_{3}{ }^{[36]}$ are known for years.

We reacted $\mathbf{3}$ and $\mathbf{4}$ with an excess of $\mathrm{Me}_{3} \mathrm{SiN}_{3}$ in the absence of any additional solvents. Complexes $\mathbf{6}$ and $\mathbf{7}$ were obtained after workup in high yields as colorless crystalline solids.

\section{Scheme 3 here}

Scheme 3. Synthesis of complexes 6 and 7.

6 and 7 don't show any sign of heat or shock sensitivity in our hands. Both are crystalline solids which melt without decomposition $\left(110^{\circ} \mathrm{C} 6,125^{\circ} \mathrm{C} 7\right)$. However, decomposition occurs $2-3^{\circ} \mathrm{C}$ above the melting points. ${ }^{1} \mathrm{H}$ and ${ }^{13} \mathrm{C}$ NMR spectra of $\mathbf{6}$ and $\mathbf{7}$ exhibit the expected resonances due to the amidinate moieties and the IR spectra each show two strong absorption bands due to the asymmetric out-of-phase N-N-N stretching frequency $\left(2027\right.$ 6, $2060 \mathrm{~cm}^{-1}$ 7) and asymmetric in-phase $S b-N_{3}$ stretching frequency $\left(20756,2093 \mathrm{~cm}^{-1}\right.$ 7). Comparable values have been reported. ${ }^{[29,32,34]}$ Expected absorption bands due to the symmetric N-N-N stretching frequency (around $1300 \mathrm{~cm}^{-1}$ ), the N-N-N deformation mode (around $640 \mathrm{~cm}^{-1}$ ) and the Sb-N stretching frequency (around $370 \mathrm{~cm}^{-1}$ ) are overlapped by the absorption bands of the amidinate ligand. ${ }^{[37]}$ In contrast, very weak stretching frequencies due to the $2 v_{s} N_{3}$ stretching frequency $(2582,25236 ; 2574,25077)$ and the sum of asymmetric and symmetric stretching frequency $v_{s} \mathrm{~N}_{3}+v_{a s} \mathrm{~N}_{3}(3329,32916 ; 3338,33107)$ are observable.

Storage of solutions of $\mathbf{6}$ and $\mathbf{7}$ in $\mathrm{CHCl}_{3}$ at $-30{ }^{\circ} \mathrm{C}$ yielded colorless crystals of $\mathbf{6}$ and $\mathbf{7}$ suitable for single crystal X-ray diffraction studies. 6 crystallizes without any additional solvent molecules in the monoclinic space group $P 2_{1} / C$ and 7 in the triclinic space group P-1 with one additional $\mathrm{CHCl}_{3}$ molecule in the crystal lattice. The structural parameters as observed for $\mathbf{6}$ and $\mathbf{7}$ are very similar to those of $\mathbf{3}$ and $\mathbf{4}$. The amidinate moieties again adopt $\mathrm{N}, \mathrm{N}^{\prime}$-chelating $\left(\eta^{2}\right)$ coordination modes, resulting in heavily distorted "saw horse" conformations of the central $\mathrm{Sb}$ atoms, in which the stereochemically active electron lone pair adopts an equatorial position.

\section{Figure 4 here}

Figure 4. Molecular structure and atom numbering scheme of a monomeric unit of $\mathrm{L}^{1} \mathrm{Sb}\left(\mathrm{N}_{3}\right)_{2}$ 6; thermal ellipsoids are drawn at the 50\% probability level. Hydrogen atoms have been omitted for clarity. Sb1-N1 
2.2260(12), Sb1-N2 2.0918(12), Sb1-N3 2.1039(14), Sb1-N6 2.2423(14), N3-N4 1.222(2), N4-N5 1.138(2), N6-N7 1.2094(19), N7-N8 1.148(2), N1-C1 1.3131(19), N2-C1 1.3650(19); N1-C1-N2 108.00(13), N1-Sb1-N2 60.15(5), C1-N1-Sb1 93.14(19), C1-N2-Sb1 97.65(9), N2-Sb1-N3 97.85(5), N3-Sb1-N1 86.12(5), N2-Sb1-N6 88.79(5), N3Sb1-N6 83.59(6), N1-Sb1-N6 145.50(5).

\section{Figure 5 here}

Figure 5. Molecular structure and atom numbering scheme of a monomeric unit of $L^{2}\left(N_{3}\right)_{2} 7$; thermal ellipsoids are drawn at the $50 \%$ probability level. Hydrogen atoms and the $\mathrm{CHCl}_{3}$ molecule have been omitted for clarity. Sb1-N1 2.2754(10), Sb1-N2 2.1057(10), Sb1-N3 2.1764(11), Sb1-N6 2.0604(11), N3-N4 1.2075(16), N4-N5 1.1479(17), N6-N7 1.2320(16), N7-N8 1.1315(16), N1-C1 1.3244(15), N2-C1 1.3536(16); N1-C1-N2 108.32(10), N1-Sb1-N2 59.26(4), C1-N1-Sb1 92.58(7), C1-N2-Sb1 99.46(7), N2-Sb1-N3 86.05(4), N3-Sb1-N1 141.79(4), N2Sb1-N6 98.08(4), N3-Sb1-N6 87.37(4), N1-Sb1-N6 82.68(4).

As was observed for the corresponding fluorides $(3,4)$ and chlorides, ${ }^{[12]}$ the $\mathrm{N}-\mathrm{Sb}-\mathrm{N}$ axes significantly deviate from linearity (N1-Sb1-N6 145.50(5) ${ }^{\circ}$ 6; N1-Sb1-N3 141.79(4) ${ }^{\circ}$ 7) and the Sb- $\mathrm{N}_{\mathrm{ax}}$ bonds (6: Sb1-N1 2.2260(12); Sb1-N6 2.2423(14); 7: Sb1-N1 2.2754(10); Sb1-N3 2.1764(11) Å) are elongated compared to Sb-N $\mathrm{N}_{\text {eq }}$ bonds (6: Sb1-N2 2.0918(12); Sb1-N3 2.1039(14); 7: Sb1-N2 2.1057(10); Sb1-N6 2.0604(11) Å). In particular the long Sb1$\mathrm{N} 1$ bond as observed in $\mathbf{7}$ indicates the somewhat more pronounced repulsive interactions due to the larger Dipp substituents bound to the $\mathrm{N}$ centers. The sum of bond angles at $\mathrm{C} 1(360.06,7), \mathrm{N} 1(357.26 ; 356.77)$ and N2 $(359.96 ; 360.07)$ is typical for $\mathrm{sp}^{2}$-hybridized carbon and nitrogen atoms as was observed for the fluorides 3 and 4, respectively, with rather localized $\pi$-electrons (6: C1-N1 1.3131(19); C1-N2 1.3650(19); 7: C1-N1 1.3244(15); C1-N2 1.3536(16) Å). The azide units both in 6 and $\mathbf{7}$ are almost linear with $\mathrm{N}-\mathrm{N}-\mathrm{N}$ bond angles of $176.86(17)$ and $177.41(17)^{\circ}(6)$ as well as $176.46(14)$ and $174.41(13)^{\circ}(7)$, respectively. Comparable values have been observed for $\mathrm{Sb}\left(\mathrm{N}_{3}\right)_{3}\left(178.3(5)^{\circ}\right)^{[30]}$ and $\mathrm{SbCl}\left(\mathrm{N}_{3}\right)_{2}\left(177(1), 178.8(9)^{\circ}\right){ }^{[31]}$ The $\mathrm{N}_{\alpha}-\mathrm{N}_{\beta}$ bond lengths (6: N3-N4 1.222(2); N6-N7 1.2094(19); 7: N3-N4 1.2075(16); N6-N7 1.2320(16) $\AA$ ) are longer than the $\mathrm{N}_{\beta}-\mathrm{N}_{\gamma}$ bond lengths

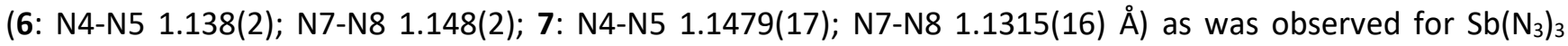
(1.233(6), 1.131(6) $\AA),{ }^{[30]}\left[\mathrm{N}_{3} \mathrm{Sb}(\mu-\mathrm{N} t-\mathrm{Bu})\right]_{2}\left(1.222(5), 1.133(5) \AA{ }^{[33 b]}\right.$ and as well as in $\mathrm{Sb}(\mathrm{V})$ azides such as $\mathrm{Ph}_{4} \mathrm{SbN}_{3}(1.198(4), 1.150(4) \AA)^{[}{ }^{[38]}$ and $\left[\mathrm{Ph}_{4} \mathrm{P}\right]\left[\mathrm{Sb}\left(\mathrm{N}_{3}\right)_{6}\right]$ (av. values 1.22 and $1.12 \AA$ ), ${ }^{[39]}$ respectively.

\section{Conclusion}


Difluorostibines of the type $\left[R C\left(N R^{\prime}\right)_{2}\right] \operatorname{SbF}_{2}(3,4)$ have been prepared in good yields by metathesis reactions. They are suitable starting reagents for the synthesis of the corresponding diazides $\left[\operatorname{RC}(\operatorname{NR})_{2}\right] \operatorname{Sb}\left(N_{3}\right)_{2}(6,7)$, which were prepared in excellent yields by reaction with $\mathrm{Me}_{3} \mathrm{SiN}_{3} .6$ and 7 , whose solid state structures were determined by single crystal X-ray diffraction, represent rare examples of structurally characterized $\mathrm{Sb}(I I I)$ azides.

\section{Experimental Section}

General Procedures. All manipulations were performed under an argon atmosphere using standard Schlenk techniques or in an inert atmosphere glove box. Solvents were dried over $\mathrm{Na} / \mathrm{K}\left(\mathrm{Et}_{2} \mathrm{O}\right)$ and $\mathrm{CaH}_{2}\left(\mathrm{CHCl}_{3}\right)$ and degassed prior to use. ${ }^{1} \mathrm{H}$ and ${ }^{13} \mathrm{C}\left\{{ }^{1} \mathrm{H}\right\}$ NMR spectra were recorded on a Bruker Avance 300 spectrometer and are referenced to internal $\mathrm{CDCl}_{3}\left({ }^{1} \mathrm{H}: \delta=7.26 ;{ }^{13} \mathrm{C}: \delta=77.0\right)$. $\mathrm{SbF}_{3}, \mathrm{LiAlH}_{4}, \mathrm{~K}$, and $\mathrm{Me}_{3} \mathrm{SiN}_{3}$ were commercially available and used as received. Li-amidinates $\mathrm{Li}\left[t-\mathrm{BuC}(\mathrm{NR})_{2}\right]$ were prepared in quantitative yield by reaction of $t$-BuLi with the corresponding carbodiimide. IR spectra were recorded on a ALPHA-T FT-IR spectrometer equipped with a single reflection ATR sampling module. Melting points were measured in sealed capillaries and were not corrected. Elemental analyses were performed at the Elementaranalyse Labor of the University of Essen.

Caution. Covalent azides are potentially hazardous and can decompose explosively under various conditions! Even though 6 and $\mathbf{7}$ in our hands did not show any sign of shock and heat sensitivity, appropriate safety precautions (safety shields, face shields, leather gloves, protective clothing) should be taken, particularly when dealing with larger quantities.

General Preparation of $\mathrm{LSbF}_{2}$ : Solid Li[tBuC(NR') $\left.)_{2}\right]\left(\mathrm{R}^{\prime}=i \operatorname{Pr} \mathrm{L}^{1}\right.$, Dipp $\left.\mathrm{L}^{2}\right)$ was slowly added within $1 \mathrm{~h}$ to a solution of $\mathrm{SbF}_{3}$ in $50 \mathrm{~mL}$ of $\mathrm{Et}_{2} \mathrm{O}$ at $-78^{\circ} \mathrm{C}$, stirred for $1 \mathrm{~h}$ and then warmed to ambient temperature over a period of $6 \mathrm{~h}$. The resulting precipitate was filtered and extracted two times with $\mathrm{CHCl}_{3}(40 \mathrm{~mL})$. The solvent was evaporated in vacuum, yielding grey crystalline solids, respectively.

$\mathrm{L}^{1} \mathrm{SbF}_{2}$ 3. $t \mathrm{BuC}(\mathrm{NiPr})_{2} \mathrm{Li}(2.50 \mathrm{~g}, 13.14 \mathrm{mmol}), \mathrm{SbF}_{3}(2.35 \mathrm{~g}, 13.14 \mathrm{mmol})$. Yield $3.33 \mathrm{~g}(9.72 \mathrm{mmol}, 74 \%)$. Melting point: $99{ }^{\circ} \mathrm{C}$. Elemental Analysis calcd (\%) for $\mathrm{C}_{11} \mathrm{H}_{23} \mathrm{~N}_{2} \mathrm{SbF}_{2}(343.07 \mathrm{~g} / \mathrm{mol}): \mathrm{H} 6.76, \mathrm{C} 38.51, \mathrm{~N} 8.17$; found: $\mathrm{H}$ 6.68, C 38.49, N 8.11. ${ }^{1} \mathrm{H}$ NMR $\left(300 \mathrm{MHz}, \mathrm{CDCl}_{3}, 25^{\circ} \mathrm{C}\right): \delta 1.28\left(\mathrm{~d},{ }^{3} \mathrm{~J}_{\mathrm{HH}}=6.3 \mathrm{~Hz}, 12 \mathrm{H}, \mathrm{CH}\left(\mathrm{CH}_{3}\right)_{2}\right), 1.44(\mathrm{~s}, 9 \mathrm{H}, t-\mathrm{Bu})$, $4.56\left(\operatorname{sep},{ }^{3} \mathrm{~J}_{\mathrm{HH}}=6.3 \mathrm{~Hz}, 2 \mathrm{H}, \mathrm{CH}\left(\mathrm{CH}_{3}\right)_{2}\right) .{ }^{13} \mathrm{C} \mathrm{NMR}\left(75 \mathrm{MHz}, \mathrm{CDCl}_{3}, 25{ }^{\circ} \mathrm{C}\right): \delta 24.3\left(\mathrm{CHMe}_{2}\right), 29.3\left(\mathrm{CMe}_{3}\right), 40.3$ 
(CMe $), 47.2\left(\mathrm{CHMe}_{2}\right), 175.4\left(\mathrm{CN}_{2}\right) \cdot{ }^{19} \mathrm{~F} \mathrm{NMR}\left(282 \mathrm{MHz}, \mathrm{CDCl}_{3}, 25^{\circ} \mathrm{C}\right): \delta$-107.9. IR: v 3010 (w), 2963 (s), 2927 (m), $2870(\mathrm{~m}), 1729(\mathrm{w}), 1621(\mathrm{w}), 1511(\mathrm{~s}), 1462(\mathrm{~m}), 1405(\mathrm{~s}), 1378(\mathrm{~s}), 1359(\mathrm{~s}), 1307(\mathrm{~s}), 1191(\mathrm{~s}), 1129(\mathrm{~s})$, $1053(\mathrm{~s}), 1027(\mathrm{~m}), 925(\mathrm{w}), 803(\mathrm{w}), 719(\mathrm{~m}), 699(\mathrm{~m}), 680(\mathrm{~m}), 559(\mathrm{vs}), 482(\mathrm{vs}) \mathrm{cm}^{-1}$.

$\mathrm{L}^{2} \mathrm{SbF}_{2}$ 4. $t \mathrm{BuC}(\mathrm{NDipp})_{2} \mathrm{Li}(2.00 \mathrm{~g}, 4.69 \mathrm{mmol}), \mathrm{SbF}_{3}(0.84 \mathrm{~g}, 4.69 \mathrm{mmol})$. Yield $2.15 \mathrm{~g}(3.71 \mathrm{mmol}, 79 \%)$. Melting point: $175{ }^{\circ} \mathrm{C}$. Elemental Analysis calcd (\%) for $\mathrm{C}_{29} \mathrm{H}_{43} \mathrm{~N}_{2} \mathrm{SbF}_{2}(579.42 \mathrm{~g} / \mathrm{mol}): \mathrm{H} 7.48, \mathrm{C} 60.11, \mathrm{~N} 4.83$; found: $\mathrm{H}$ 7.25, C 59.87, N 4.51. ${ }^{1} \mathrm{H}$ NMR (300 MHz, $\left.\mathrm{CDCl}_{3}, 25^{\circ} \mathrm{C}\right): \delta 1.06(\mathrm{~s}, 9 \mathrm{H}, t-\mathrm{Bu}), 1.38\left(\mathrm{~d},{ }^{3} \mathrm{~J}_{\mathrm{HH}}=6.8 \mathrm{~Hz}, 12 \mathrm{H}, \mathrm{CH}\left(\mathrm{CH}_{3}\right)_{2}\right)$, $1.45\left(\mathrm{~d},{ }^{3} \mathrm{~J}_{\mathrm{HH}}=6.9 \mathrm{~Hz}, 12 \mathrm{H}, \mathrm{CH}\left(\mathrm{CH}_{3}\right)_{2}\right), 3.44\left(\mathrm{~m}, 4 \mathrm{H}, \mathrm{CH}\left(\mathrm{CH}_{3}\right)_{2}\right), 7.27(\mathrm{~m}, 6 \mathrm{H}, \mathrm{ArH}) .{ }^{13} \mathrm{C} \mathrm{NMR}\left(75 \mathrm{MHz}, \mathrm{CDCl}_{3}, 25^{\circ} \mathrm{C}\right)$ : $\delta 22.6$ ( $\mathrm{CHMe} 2), 26.5\left(\mathrm{CHMe}_{2}\right), 29.0$ (CMe $), 42.1$ (CMe $), 123.0$ (C4), 123.5 (C3/C5), 126.8 (C2/C6), 144.6 (N-C1), $175.3\left(\mathrm{CN}_{2}\right) .{ }^{19} \mathrm{~F}$ NMR $\left(282 \mathrm{MHz}, \mathrm{CDCl}_{3}, 25^{\circ} \mathrm{C}\right): \delta$-115.3. IR: $v 2960(\mathrm{~s}), 2929(\mathrm{~m}), 2869(\mathrm{~m}) 1618(\mathrm{w}) 1527(\mathrm{~m})$ 1439 (s) 1361 (s), 1319 (s), 1255 (w), 1213 (w), 1181 (s), 1097 (m), 1044 (w), $980(w), 953$ (w), $934(w), 803$ (s), 764 (w), 588 (vs), 516 (vs), 425 (s) $\mathrm{cm}^{-1}$.

$\mathrm{L}^{1} \mathrm{Sb}\left(\mathrm{N}_{3}\right)_{2}$ 6. $t \mathrm{BuC}(\mathrm{NiPr})_{2} \mathrm{SbF}_{2}(0.50 \mathrm{~g}, 1.46 \mathrm{mmol}), \mathrm{Me}_{3} \mathrm{SiN}_{3}(0.69 \mathrm{~g}, 5.99 \mathrm{mmol})$. Yield $0.53 \mathrm{~g}(1.36 \mathrm{mmol}, 93 \%)$. Melting point: $110{ }^{\circ} \mathrm{C}$; smooth decomposition starts at $112{ }^{\circ} \mathrm{C}$. Elemental Analysis calcd (\%) for $\mathrm{C}_{11} \mathrm{H}_{23} \mathrm{~N}_{8} \mathrm{Sb}$ (389.11 g/mol): found (calcd): H 5.96, C 33.95, N 28.80; found: H 6.02, C 33.46, N 28.48. ${ }^{1} \mathrm{H}$ NMR (300 MHz, $\left.\mathrm{CDCl}_{3}, 25^{\circ} \mathrm{C}\right): \delta 1.31\left(\mathrm{~d}, 3^{3} \mathrm{~J}_{\mathrm{HH}}=6.3 \mathrm{~Hz}, 12 \mathrm{H}, \mathrm{CH}\left(\mathrm{CH}_{3}\right)_{2}\right), 1.48(\mathrm{~s}, 9 \mathrm{H}, t-\mathrm{Bu}), 4.56\left(\mathrm{sep},{ }^{3} \mathrm{JHH}_{\mathrm{HH}}=6.3 \mathrm{~Hz}, 2 \mathrm{H}, \mathrm{CH}\left(\mathrm{CH}_{3}\right)_{2}\right)$. ${ }^{13} \mathrm{C} \mathrm{NMR}\left(75 \mathrm{MHz}, \mathrm{CDCl}_{3}, 25{ }^{\circ} \mathrm{C}\right): \delta 24.1\left(\mathrm{CHMe}_{2}\right), 29.7\left(\mathrm{CMe}_{3}\right), 40.8\left(\mathrm{CMe}_{3}\right), 47.8\left(\mathrm{CHMe}_{2}\right), 175.9\left(\mathrm{CN}_{2}\right)$. IR: v 3329 (w), 3291 (w), 2967 (s), 2926 (m), $2871(\mathrm{~m}), 2582$ (w), 2523 (w), 2075 (vs), 2027 (vs), 1618 (m), 1510 (s), $1455(\mathrm{~m}), 1307(\mathrm{~s}), 1265(\mathrm{~s}), 1186(\mathrm{~s}), 1131(\mathrm{~m}), 1052(\mathrm{~m}), 926(\mathrm{w}), 840(\mathrm{w}), 676(\mathrm{~m}), 493(\mathrm{~m}), 399(\mathrm{~s}) \mathrm{cm}^{-1}$.

$\mathrm{L}^{2} \mathrm{Sb}\left(\mathrm{N}_{3}\right)_{2}$ 7. $t \mathrm{BuC}(\mathrm{NDipp})_{2} \mathrm{SbF}_{2}(1.20 \mathrm{~g}, 2.07 \mathrm{mmol}), \mathrm{Me}_{3} \mathrm{SiN}_{3}(0.95 \mathrm{~g}, 8.28 \mathrm{mmol})$. Yield $1.22 \mathrm{~g}(1.95 \mathrm{mmol}, 94 \%)$. Melting point: $125{ }^{\circ} \mathrm{C}$; smooth decomposition starts at $127{ }^{\circ} \mathrm{C}$. Elemental Analysis calcd (\%) for $\mathrm{C}_{29} \mathrm{H}_{43} \mathrm{~N}_{8} \mathrm{Sb}$ (625.47 g/mol): H 6.93, C 55.69, N 17.92; found: H 6.97, C 55.53, N 17.79. ${ }^{1} \mathrm{H}$ NMR (300 MHz, $\left.\mathrm{CDCl}_{3}, 25{ }^{\circ} \mathrm{C}\right): \delta$ $1.03(\mathrm{~s}, 9 \mathrm{H}, t-\mathrm{Bu}), 1.41\left(\mathrm{~d},{ }^{3} \mathrm{~J}_{\mathrm{HH}}=6.8 \mathrm{~Hz}, 12 \mathrm{H}, \mathrm{CH}\left(\mathrm{CH}_{3}\right)_{2}\right), 1.43\left(\mathrm{~d},{ }^{3} \mathrm{~J}_{\mathrm{HH}}=6.8 \mathrm{~Hz}, 12 \mathrm{H}, \mathrm{CH}\left(\mathrm{CH}_{3}\right)_{2}\right), 3.36(\mathrm{~m}, 4 \mathrm{H}$, $\left.\mathrm{CH}\left(\mathrm{CH}_{3}\right)_{2}\right), 7.28(\mathrm{~m}, 6 \mathrm{H}, \mathrm{ArH}) .{ }^{13} \mathrm{C} \mathrm{NMR}\left(75 \mathrm{MHz}, \mathrm{CDCl}_{3}, 25^{\circ} \mathrm{C}\right): \delta 23.0\left(\mathrm{CCMe}_{3}\right), 26.7\left(\mathrm{CHMe}_{2}\right), 29.1\left(\mathrm{CHMe}_{2}\right), 29.9$ (CHMe $), 41.9$ (CCMe $), 123.1$ (C4), 123.9 (C3/C5), 127.4 (C2/C6), 136.6 (N-C1), 174.8 (CCMe $) . ~ I R: ~ v 3338$ (w), $3310(w), 2961$ (s), 2931 (m), 2870 (m), 2574 (w), 2506 (w), 2093 (vs), 2060 (vs), 1657 (w), 1612 (w), 1584 (w), $1508(\mathrm{~m}), 1459(\mathrm{~m}), 1450(\mathrm{w}), 1361(\mathrm{~s}), 1318(\mathrm{~s}), 1255(\mathrm{~s}), 1177(\mathrm{~s}), 1097(\mathrm{w}), 1054(\mathrm{~m}), 933(\mathrm{w}), 805(\mathrm{~s}), 761(\mathrm{~s})$, $416(\mathrm{~s}) \mathrm{cm}^{-1}$. 
Single Crystal Structure Determination of 1 - 7. Crystallographic data of $\mathbf{3}-\mathbf{7}$ are summarized in Table 1.

Figures $1-5$ show diagrams of the solid state structures of $\mathbf{3}-\mathbf{7}$. The crystals were mounted on nylon loops in inert oil. Data were collected on a Bruker D8 Kappa diffractometer with APEX2-detector (monochromated MoK $_{\alpha}$ radiation, $\lambda=0.71073 \AA$ ) at $100(1)(\mathbf{1}-\mathbf{6})$ and $103(1) \mathrm{K}(\mathbf{7})$. The structures were solved by Direct Methods using Bruker AXS APEX 2 software ${ }^{[40]}$ and refined by full-matrix least-squares on $F^{2}$. Semi-empirical absorption corrections were applied (SADABS). All non-hydrogen atoms were refined anisotropically and hydrogen atoms by a riding model (SHELXL-97, Program for Crystal Structure Refinement). ${ }^{[41]}$

CCDC-793820 (1), -793821 (2), -793822 (3), -793825 (4), -793824 (5), -793823 (6) and -793826 (7) contain the supplementary crystallographic data for this paper. These data can be obtained free of charge from The Cambridge Crystallographic Data Centre via www.ccdc.cam.ac.uk/data_request/cif.

\section{Acknowledgements}

Financial support from the Deutsche Forschungsgemeinschaft DFG is gratefully acknowledged. B. Lyhs thanks the Fonds der Chemischen Industrie for a doctoral fellowship.

\section{References}

[1] L. Bourget-Merle, M. F. Lappert, J. R. Severn, Chem. Rev. 2002, 102, 3031.

[2] P. J. Bailey, S. Pace, Coord. Chem. Rev. 2001, 214, 91.

[3] a) J. Barker, M. Kilner, Coord. Chem. Rev. 1994, 133, 219; b) P. C. Junk, M. L. Cole, J. Chem. Soc., Chem. Commun. 2007, 1579. For a very recent recent review on amidinate and guanidinate complexes see: c) F. Edelmann, Adv. Organomet. Chem. 2008, 57, 183. The coordination chemistry of neutral amidines and guanidines was recently described: d) M. P. Coles, J. Chem. Soc., Dalton Trans. 2006, 985.

[4] See for further bindings modes: P. C. Junk, M. L. Cole, J. Chem. Soc., Chem. Commun. 2007, 1579.

[5] a) C. E. Radzewich, M. P. Coles, R. F. Jordan J. Am. Chem. Soc. 1998, 120, 9384; b) S. Dagorne, I. A. Guzei, M. P. Coles, R. F. Jordan, J. Am. Chem. Soc. 2000, 122, 274; c) Sergio Bambirra, Marco W. Bouwkamp, Auke Meetsma, and Bart Hessen, J. Am. Chem. Soc. 2004, 126, 9182. For review article see: a) S. Dagorne, D. A. Atwood, Chem. Rev. 2008, 108, 4037; b) M. Nishiura, Z. Hou, Nature Chem. 2010, 2, 257.

[6] a) A. Baunemann, D. Bekermann, T. B. Thiede, H. Parala, M. Winter, C. Gemel, R A. Fischer, J. Chem. Soc., Dalton Trans., 2008, 3715; b) J. P. Coyle, W. H. Monillas, G. P. A. Yap, S. T. Barry, Inorg. Chem. 2008, 47, 683; c) I. L. Brazeau, S. T. Barry, Chem. Mater. 2008, 20, 7287; d) J. P. Coyle, P. A. Johnson, G. A. DiLabio, S. T. Barry, Jens Müller, Inorg. Chem. 2010, 49, 2844; e) Y. A. Wasslen, E. Tois, S. Haukka, K. A. Kreisel, G. P. A. Yap, M. D. Halls, S. T. Barry, Inorg. Chem. 2010, 49, 1976. 
[7] S. P. Green, C. Jones, A. Stasch, Science 2007, 318, 1754.

[8] a) C. Cui, H. W. Roesky, H.-G. Schmidt, M. Noltemeyer, H. Hao, F. Cimpoesu, Angew. Chem., Int. Ed. Engl. 2000, 39, 4274; b) N. J. Hardman, B. E. Eichler, P. P. Power, J. Chem. Soc., Chem. Commun. 2000, 1991; c) C. Jones, P. C. Junk, J. A. Platts, A. Stasch, J. Am. Chem. Soc. 2006, 128, 2206; d) G. Jin, C. Jones, P. C. Junk, A. Stasch, W. D. Woodul, New J. Chem. 2008, 32, 835.

[9] See the following and references cited therein: a) M. Stender, A. D. Phillips, P. P. Power, Inorg. Chem. 2001, 40, 5314; b) S. P. Green, C. Jones, P. C. Junk, K.-A. Lippert, A. Stasch, J. Chem. Soc., Chem. Commun. 2006, 3978; c) A. Stasch, C. M. Forsyth, C. Jones, P. C. Junk, New J. Chem. 2008, 32, 829; d) S. Nagendran, S. S. Sen, H. W. Roesky, D. Koley, H. Grubmüller, A. Pal, R. Herbst-Irmer, Organometallics 2008, 27, 5459.

[10] a) S. P. Green, C. Jones, G. Jin, A. Stasch, Inorg. Chem. 2007, 46, 8; b) P. B. Hitchcock, M. F. Lappert, G. Li, A. V. Protchenko, J. Chem. Soc., Chem. Commun. 2009, 428.

[11] a) S. Schulz, M. Nieger, Angew. Chem. 1999, 111, 1020; Angew. Chem. Int. Ed. 1999, 38, 967; b) A. Kuczkowski, S. Schulz, M. Nieger, Organometallics 2001, 20, 2000; c) A. Kuczkowski, S. Schulz, M. Nieger, Angew. Chem. 2001, 113, 4351; Angew. Chem. Int. Ed. 2001, 40, 4222.

[12] S. Schulz, B. Lyhs, U. Westphal, D. Bläser, R. Boese, M. Bolte, Eur. J. Inorg. Chem. 2009, 2247.

[13] a) C. Ergezinger, F. Weller, K. Dehnicke, Z. Naturforsch. 1988, 43b, 1119; b) L. A. Lesikar, A. F. Richards, J. Organomet. Chem. 2006, 691, 4250; c) L. W. Pineda, V. Jancik, S. Nembenna, H. W. Roesky, Z. Anorg. Allg. Chem. 2007, 633, 2205; d) M. Brym, C. M. Forsyth, C. Jones, P. C. Junk, R. P. Rose, A. Stasch, D. A. Turner, J. Chem. Soc. Dalton Trans. 2007, 3282. In addition, a very few complexes of the types $L_{2} E X$ and $L_{3} E$ have been reported: e) U. Patt-Seibel, U. Müller, C. Ergezinger, B. Borgsen, K. Dehnicke, D. Fenske, G. Baum, Z. Anorg. Allg. Chem. 1990, 582, 30; f) C. L. Raston, R. W. Skelton, V.-A. Tolhurst, A. H. White, Polyhedron 1998, 17, 935; g) C. L. Raston, B. W. Skelton, V. A. Tolhurst, A. H. White, J. Chem. Soc., Dalton Trans. 2000, 1279.

Moreover, complexes of the type LEX 4 were structurally characterized (h) F. Weller, J. Pebler, K. Dehnicke, K.; Hartke, H.-M. Wolff Z. Anorg. Allg. Chem. 1982, 486, 61; i) W. Honeise, W. Schwarz, G. Heckmann, A. Schmidt Z. Anorg. Allg. Chem. 1986, 533, 55) and an unusual stibine complex $\left[\mathrm{Sb}\left\{(i \mathrm{PrN}){ }_{2} \mathrm{CNH} i \operatorname{Pr}\right\}\left\{(i \mathrm{PrN}){ }_{2} \mathrm{CN} i \operatorname{Pr}\right\}\right]$ containing both a guanidinate monoanion and dianion was structurally characterized (j) P. J. Bailey, R. O. Gould, C. N. Harmer, S. Pace, A. Steiner, D. S. Wright, J. Chem. Soc., Chem. Commun. 1997, 1161).

[14] a) Suzuki, H., Matano, Y., Eds. Organobismuth Chemistry; Elsevier Science B. V.: Amsterdam, 2001; b) Shimada S.; Yamazaki O.; Tanaka T.; Suzuki, Y.; Tanaka, M. J. Organomet. Chem. 2004, 689, 3012; c) A. P. Soran, C. Silvestru, H. J. Breunig, G. Balász, J. C. Green, Organometallics 2007, 26, 1196.

[15] M. L. Cole, C. Jones, P. C. Junk, M. Kloth, A. Stasch, Chem. Eur. J. 2005, 11, 4482.

[16] M. L. Cole, P. C. Junk, J. Organomet. Chem. 2003, 666, 55.

[17] Crystal data for 1: $\mathrm{C}_{58} \mathrm{H}_{90} \mathrm{Al}_{2} \mathrm{~N}_{4}, \mathrm{M}=448.65$, colorless crystal $(0.17 \times 0.12 \times 0.10 \mathrm{~mm})$; monoclinic, space group P21/n; $a=13.5773(6), b=17.7258(9), c=14.4451(7) \AA ; \beta=111.356(2)^{\circ}, V=3237.8(2) \AA^{3} ; Z=2 ; \mu=0.078$ $\mathrm{mm}^{-1} ; \rho_{\text {calc. }}=0.920 \mathrm{~g} \mathrm{~cm}^{-3} ; 36424$ reflexes $\left(2 \theta_{\max }=49.7^{\circ}\right), 5435$ unique $\left(R_{\text {merg }}=0.0335\right) ; 325$ parameters; largest max./min. in the final difference Fourier synthesis $0.438 /-0.552 \mathrm{e}^{-3} ; \mathrm{R} 1=0.0817(\mathrm{I}>2 \sigma(\mathrm{I}))$, wR2 (all data) $=$ 
0.2174. $t$-Bu carbon atoms C27 - C29 disordered over two sites with SOF 0.6 and 0.4. ADP's of C9 and C25 indicate severe disorder problems, which could not be resolved. Crystal data for 2: $\mathrm{C}_{25} \mathrm{H}_{36} \mathrm{~N}_{2} \times \mathrm{C}_{25} \mathrm{H}_{35} \mathrm{~N}_{2} \mathrm{~K} x$ $3\left[\mathrm{C}_{4} \mathrm{H}_{8} \mathrm{O}\right], \mathrm{M}=983.52$, colorless crystal $(0.23 \times 0.17 \times 0.12 \mathrm{~mm})$; monoclinic, space group $\mathrm{P} 21 / \mathrm{n} ; \mathrm{a}=17.4065(6)$, $b=17.1308(6), c=21.0945(9) \AA ; ; \beta=107.3790(10)^{\circ}, V=6003.0(4) \AA^{3} ; Z=4 ; \mu=0.133 \mathrm{~mm}^{-1} ; \rho_{\text {calc. }}=1.088 \mathrm{~g} \mathrm{~cm}^{-}$ 3; 36562 reflexes $\left(2 \theta_{\max }=51.2^{\circ}\right), 11254$ unique $\left(R_{\operatorname{merg}}=0.0416\right) ; 631$ parameters; largest max./min. in the final difference Fourier synthesis 0.500/-0.488 e $\AA^{-3} ; R 1=0.0488(I>2 \sigma(I))$, wR2 (all data) $=0.1439$. ADP's of C58 and C83 indicate severe disorder problems, which could not be resolved.

[18] B. R. Jagirdar, E. F. Murphy, H. W. Roesky, in: K. D. Karlin (Ed.), Progress in Inorganic Chemistry, vol. 48, John Wiley and Sons, 1999, pp. 351-455 and references cited therein.

[19] S. P. Bone, D. B. Sowerby, J. Chem. Soc., Dalton Trans. 1979, 1430.

[20] a) K. Ohkata, S. Takemoto, M. Ohnishi, K. Akiba, Tetrahedron Lett. 1989, 30, 4841; b) L. Baiget, M. Bouslikhane, J. Escudie, G. C. Nemes, I. Silaghi-Dumitrescu, L. Silaghi-Dumitrescu, Phosphorus, Sulfur and Silicon 2003, 178, 1949.

[21] L. Dostál, R. Jambor, A. Růžička, R. Jirásko, I. Císařová, J. Holeček, J. Fluor. Chem. 2008, 129, 167.

[22] See the following and references cited therein: a) S. Chitsaz, K. Dehnicke, G. Frenzen, A. Pilz, U. Müller, Z. Anorg. Allg. Chem. 1996, 622, 2016; b) G. Alonzo, N. Bertazzi, G. Bombieri, G. Bruno, J. Chem. Soc., Dalton Trans. 1987, 2337; c) P. L. Shutov, S. S. Karlov, K. Harms, D. A. Tyurin, J. Sundermeyer, J. Lorberth, G. S. Zaitseva, Eur. J. Inorg. Chem. 2004, 2498.

[23] Y. Yamamoto, S. Kojima, H. Fujishima, H. Fujikawa, K. Akiba, Bull. Soc. Chim. Belg. 1997, 106, 651.

[24] J. Baldamus, C. Berghof, M. L. Cole, D. J. Evans, E. Hey-Hawkins, P. C. Junk, J. Chem. Soc., Dalton Trans. 2002, 2802.

[25] a) M. L. Cole, A. J. Davies, C. Jones, P. C. Junk, J. Organomet. Chem. 2007, 692, 2508; b) G. B. Deacon, C. M. Forsyth, P. C. Junk, J. Wang, Inorg. Chem. 2007, 46, 10022.

[26] G. Jin, C. Jones, P. C. Junk, K.-A. Lippert, R. P. Rose, A. Stasch, New J. Chem. 2009, 33, 64.

[27] A structure search in the Cambridge Structural Database for $\mathrm{N}_{\text {aryl-substituted Li-amidinates gave } 48 \text { entries }}$ with an average $\mathrm{CNC}$ bond angle of $117.64^{\circ}\left(\mathrm{min} / \max : 113.94 / 121.21^{\circ}\right)$.

[28] A structure search in the Cambridge Structural Database for $\mathrm{SbF}_{3}$ gave nine entries with Sb-F bond length ranging from 1.90 to $1.93 \AA$ and an average value of $1.924 \AA$.

[29] a) M. K. Rastogi, Synth. React. Inorg. Met.-Org. Chem. 1987, 17, 525; b) A. K. Saxena, A. Ranjan, Synth. React. Inorg. Met.-Org. Chem. 1999, 29, 1579.

[30] a) T. M. Klapötke, A. Schulz, J. McNamara, J. Chem. Soc., Dalton Trans. 1996, 2985; b) R. Haiges, A. Vij, J. A. Boatz, S. Schneider, T. Schroer, M. Gerken, K. O. Christe, Chem. Eur. J. 2004, 10, 508.

[31] T. M. Klapötke, H. Nöth, T. Schütt, M. Warchold, Z. Anorg. Allg. Chem. 2001, 627, 81.

[32] T. M. Klapötke, H. Nöth, T. Schütt, M. Suter, Eur. J. Inorg. Chem. 2002, 2511.

[33] a) D. F. Moser, I. Schranz, M. C. Gerrety, L. Stahl, R. J. Staples, J. Chem. Soc., Dalton Trans. 1999, 751; b) D. C. Haagenson, L. Stahl, R. J. Staples, Inorg. Chem. 2001, 40, 4491. 
[34] J. Müller, U. Müller, A. Loss, J. Lorberth, H. Donath, W. Massa, Z. Naturforsch. 1985, 40b, 1320.

[35] A. Villinger, A. Schulz, Angew. Chem. 2010, 122, 8190; Angew. Chem. Int. Ed. 2010, 49, 8017.

[36] J. Müller, Z. Anorg. Allg. Chem. 1973, 381, 103.

[37] a) W. Beck, W. P. Fehlhammer, P. Pollmann, E. Schuierer, K. Feldl, Chem. Ber. 1967, 100, 2335; b) Z. Dori, R.

F. Ziolo, Chem. Rev. 1973, 73, 247.

[38] R. Haiges, T. Schroer, M. Yousufuddin, K. O. Christe, Z. Anorg. Allg. Chem. 2005, 631, 2691.

[39] R. Haiges, J. A. Boatz, A. Vij, V. Vij, M. Gerken, S. Schneider, T. Schroer, M. Yousufuddin, K. O. Christe, Angew. Chem. 2004, 116, 6844; Angew. Chem. Int. Ed. 2004, 43, 6676.

[40] G. M. Sheldrick, SHELXS-97, Program for Structure Solution: Acta Crystallogr. Sect. A 1990, 46, 467.

[41] G. M. Sheldrick, SHELXL-97, Program for Crystal Structure Refinement, Univ. Göttingen, 1997. See also: G. M. Sheldrick, Acta Cryst., 2008, A64, 112. 
Table 1. Crystallographic data for $\operatorname{LSbF}_{2}\left(\mathrm{~L}^{1} \mathbf{3}, \mathrm{L}^{2} \mathbf{4}\right),\left[\mathrm{L}^{2} \mathrm{SbF} \mathrm{F}_{2}\left[\mathrm{~L}^{2} \mathrm{Li}\right] \mathbf{5}\right.$, and $\operatorname{LSb}\left(\mathrm{N}_{3}\right)_{2}\left(\mathrm{~L}^{1} \mathbf{6}, \mathrm{L}^{2} \mathbf{7}\right)$.

\begin{tabular}{|c|c|c|c|c|c|}
\hline & 3 & $4^{[\mathrm{d}]}$ & $5^{[\mathrm{e}]}$ & 6 & 7 \\
\hline \multirow[t]{2}{*}{ empirical formula } & $\mathrm{C}_{11} \mathrm{H}_{23} \mathrm{~F}_{2} \mathrm{~N}_{2} \mathrm{Sb} x$ & $\mathrm{C}_{29} \mathrm{H}_{43} \mathrm{~F}_{2} \mathrm{~N}_{2} \mathrm{Sb} x$ & $\mathrm{C}_{58} \mathrm{H}_{86} \mathrm{~F}_{2} \mathrm{LiN}_{4} \mathrm{~S}$ & $\mathrm{C}_{11} \mathrm{H}_{23} \mathrm{~N}_{8} \mathrm{Sb}$ & $\mathrm{C}_{29} \mathrm{H}_{43} \mathrm{~N}_{8} \mathrm{Sb} \times$ \\
\hline & $\mathrm{CHCl}_{3}$ & $\mathrm{CHCl}_{3}$ & $b$ & & $\mathrm{CHCl}_{3}$ \\
\hline molecular mass & 462.43 & 698.77 & 1006.00 & 389.12 & 744.83 \\
\hline crystal system & triclinic & triclinic & monoclinic & monoclinic & triclinic \\
\hline space group & P-1 & $P-1$ & $\mathrm{C} 2 / \mathrm{c}$ & $\mathrm{P} 2_{1} / \mathrm{c}$ & P-1 \\
\hline $\mathrm{a}[\AA ̊]$ & $8.8123(5)$ & $8.0325(3)$ & $28.4769(12)$ & $13.4446(4)$ & $8.4752(4)$ \\
\hline $\mathrm{b}[\AA ̊]$ & $10.3658(6)$ & $11.0837(4)$ & $10.6263(5)$ & $9.1258(2)$ & $12.1393(6)$ \\
\hline$c[\AA]$ & $10.9186(7)$ & $18.7846(7)$ & $39.2972(17)$ & $15.0871(4)$ & $17.4195(8)$ \\
\hline$\alpha[\mathrm{deg}]$ & $102.624(2)$ & $82.002(2)$ & 90 & 90 & $94.073(2)$ \\
\hline$\beta$ [deg] & $108.436(2)$ & $87.664(2)$ & $108.674(2)$ & $115.987(1)$ & $93.135(2)$ \\
\hline$\gamma[\mathrm{deg}]$ & $95.151(2)$ & $80.905(2)$ & 90 & 90 & $105.979(2)$ \\
\hline$V\left[\AA^{3}\right]$ & 909.61(9) & $1635.00(10)$ & 11265.5(9) & 1663.92(8) & 1713.42(14) \\
\hline Z & 2 & 2 & 8 & 4 & 2 \\
\hline$\mu\left[\mathrm{mm}^{-1}\right]$ & 1.968 & 1.122 & 0.534 & 1.663 & 1.072 \\
\hline $\mathrm{D}_{\text {calcd. }}\left[\mathrm{g} \mathrm{cm}^{-3}\right]$ & 1.688 & 1.419 & 1.186 & 1.553 & 1.444 \\
\hline $2 \theta_{\max }[\mathrm{deg}]$ & 56.8 & 52.4 & 48.0 & 54.2 & 56.6 \\
\hline \multirow[t]{2}{*}{ cryst. $\operatorname{dim}[\mathrm{mm}]$} & $0.38 \times 0.22 x$ & $0.24 \times 0.20 x$ & $0.28 \times 0.23 \times$ & $0.34 \times 0.28 x$ & $0.32 \times 0.27 x$ \\
\hline & 0.20 & 0.15 & 0.18 & 0.07 & 0.23 \\
\hline no. of reflns. & 14013 & 24183 & 33192 & 15761 & 33355 \\
\hline no. uniq. reflns. & 4488 & 6462 & 8273 & 3660 & 8486 \\
\hline$R_{\text {int }}$ & 0.0194 & 0.0201 & 0.0439 & 0.0191 & 0.0205 \\
\hline $\begin{array}{l}\text { no. of param. } \\
\text { ref./restraints }\end{array}$ & 181 / 0 & 370 / 0 & $604 / 0$ & 181 / 0 & 379 / 0 \\
\hline$R 1^{[a]}$ & 0.0170 & 0.0352 & 0.0535 & 0.0156 & 0.0180 \\
\hline$w R 2^{[\mathrm{b}]}$ & 0.0411 & 0.0935 & 0.0997 & 0.0394 & 0.0474 \\
\hline goodness of fit ${ }^{[c]}$ & 1.052 & 1.095 & 1.130 & 1.077 & 1.073 \\
\hline $\begin{array}{c}\text { final } \max / \min . \Delta \rho, \mathrm{e} \\
\AA^{-3}\end{array}$ & $0.771 /-0.575$ & $1.948 /-1.038$ & $0.491 /-1.320$ & $0.873 /-0.270$ & $0.740 /-0.276$ \\
\hline
\end{tabular}

[a] $R 1=\Sigma\left(|| F_{\mathrm{o}}|-| F_{\mathrm{c}}||\right) / \Sigma\left|F_{\mathrm{o}}\right|($ for $\mathrm{I}>2 \sigma(\mathrm{I})) .-[\mathrm{b}] w R 2=\left\{\Sigma\left[w\left(F_{\mathrm{o}}^{2}-F_{\mathrm{c}}^{2}\right)^{2}\right] / \Sigma\left[w\left(F_{\mathrm{o}}^{2}\right)^{2}\right]\right\}^{1 / 2}$. (for all data) $w^{-1}=\sigma^{2}\left(F_{\mathrm{o}}{ }^{2}\right)+$ $(a P)^{2}+b P$ with $P=\left[F_{\mathrm{o}}{ }^{2}+2 F_{\mathrm{c}}^{2}\right] / 3, a$ and $b$ are constants chosen by the programme $-[\mathrm{c}]$ Goodness of fit $=$ $\left\{\Sigma\left[w\left(\left|F_{0}^{2}\right|-\left|F_{c}^{2}\right|\right)^{2}\right] /\left(N_{\text {observns }}-N_{\text {params }}\right)\right\}^{1 / 2}$. - [d] $t$ Bu carbon atoms C27 - C29 disordered over two sites with SOF 0.5. - [e] Fluorine atoms $F(2)$ disordered over two sites with SOF 0.8 and 0.2 . 


\section{Entry for the Table of Contents}

Layout 1

$\mathrm{Sb}(I I I)$ bisazides

Benjamin Lyhs, Dieter Bläser, Christoph Wölper, and Stephan Schulz*

Syntheses and X-Ray Crystal Structures of Organoantimony Diazides

Antimony(III)bisazides $\mathrm{LSb}\left(\mathrm{N}_{3}\right)_{2}(\mathrm{~L}=$ amidinate) were synthesized by reaction of the corresponding fluorides $\mathrm{LSbF}_{2}$ with $\mathrm{Me}_{3} \mathrm{SiN}_{3}$. 


\section{DuEPublico}

This text is made available via DuEPublico, the institutional repository of the University of Duisburg-Essen. This version may eventually differ from another version distributed by a commercial publisher.

DOI: $\quad 10.1002 /$ chem. 201002730

URN: urn:nbn:de:hbz:464-20201110-093747-2

This is the peer reviewed version of the following article: Chemistry - A European Journal, 2011, Volume 17, Issue 17, Pages 4914-4920, which has been published in final form at: https://doi.org/10.1002/chem.201002730

All rights reserved. 